\title{
How the Finnish compulsory school science curriculum emphasises scientific literacy
}

\author{
Jari Lavonen ${ }^{\text {a1 }}$ \\ ${ }^{a}$ Faculty of Educational Sciences, University of Helsinki, Finland
}

\begin{abstract}
Science subjects are introduced as separate subjects in the Finnish national lowersecondary level science curriculum. The curriculum concentrates on attitudes, which support the use of scientific knowledge in different science inquiry situations and contexts. The competence aims, introduced in the curriculum, emphasise the use of scientific knowledge, such as describing, explaining and predicting scientific phenomena, evaluating and identifying scientific issues, and interpreting data and evidence scientifically. The curriculum emphasises the learning of transversal competencies, such as learning critical and creative thinking skills and learning versatile ways of working. The curriculum also focuses on the use of knowledge in inquiry, life and living and society related situations. Overall, the description of the core subject matter knowledge aims to integrate Vision I (a conceptual approach) and Vision II (a contextual approach) related to the development of science literacy, introduced by Roberts.
\end{abstract}

Keywords: science curriculum, scientific literacy, transversal competencies

\section{Introduction}

First of all, the meaning of scientific literacy and transversal competencies is analysed in the introduction, showing how the discussions about scientific literacy and transversal competencies in international education policy discourse have influenced the Finnish compulsory school science curriculum. This will be followed by a short overview of the curriculum to support the understanding of the nature of the Finnish compulsory school curriculum. These analyses provide the setting for the aim of this article.

\section{Scientific literacy}

The concept "scientific literacy" or "science literacy" has been used in curriculum documents and science education research papers since the 1950s (Roberts, 2007). In fact, scientific literacy has been set as a core aim for science 
education in various curriculum documents. However, scientific literacy and its components have various meanings and are portrayed in a variety of ways in describing the aims, objectives and content, or subject matter in the curriculum (DeBoer, 2000; Roberts \& Bybee, 2014). For example, DeBoer (2000) introduces nine different definitions of scientific literacy. Within these, one important discussion has been whether scientific literacy is analysed in terms of science subject matter knowledge or skills and wider competencies.

Roberts (2007) has proposed two scientific knowledge related views or visions for scientific literacy from the point of view of science subject matter: Vision I emphasises the knowledge within science and, hence, teaching the core science subject knowledge. Vision II concerns knowledge about science and focuses on public understanding of science, emphasising applications of science in various personal, local and global contexts. Hodson (2011) has, in promoting competencies, introduced the new Vision III and named this as 'critical scientific literacy' (cf., Levinson, 2010). Vision III focuses on sociopolitical engagement for value-driven transformations of both the individual and society. One well-known teaching approach using Vision III emphasises socio-scientific issues (SSI) in science education (Sjöström et al., 2017). However, these three visions are not appropriate for analysing the Finnish compulsory school science curriculum because the curriculum requires competencies - not subject matter knowledge. On the other hand, introduced visions do not emphasise only the subject matter. For example, Holbrook (2010) includes the applying of knowledge and functional competencies to vision II.

A well-known scientific literacy approach, which emphasises skills and competencies, is the Scientific Literacy Framework, introduced in the Programme for International Student Assessment (PISA) (Organisation for Economic Co-operation and Development in 2007, but revised in 2013. [OECD], 2013). The old and new frameworks introduce the concept of scientific literacy, which refers to knowledge of both science and science-based technology plus the use of this knowledge in making informed choices. But it is also appropriate to refer to an earlier, initial PISA Scientific Literacy Framework (OECD, 2007) because it has also been influential in guiding curriculum development. This framework initially defines three competencies, which describe the use of science subject knowledge and knowledge about science and, moreover, willingness (attitude) to use this knowledge in three situations (skills): in identifying scientific issues, in explaining scientific phenomena and in drawing evidence-based conclusions (OECD, 2007). This framework also concentrates on various situations or contexts where attitude, knowledge and skills are developed. According to Bybee and McCrae (2011), the PISA framework is a guideline for promoting scientifically literate persons in adulthood. Thus, this 
PISA framework includes the idea that competencies as described are useful in various problem-solving situations in adulthood - they are transferable to new situations. In a nutshell, the PISA Scientific Literacy Framework emphasises the use of scientific knowledge and a willingness to use this knowledge in three processes and three situations or contexts (OECD, 2007):

1) Attitudes are a key component of an individual's science competence and include an individual's values, motivational orientations and sense of selfefficacy. Attitudes and engagement with science are measured in four areas: support for scientific enquiry, self-belief as science learners, interest in science, plus responsibility towards resources and environments.

2) Scientific knowledge or concepts constitute the links that aid understanding of related phenomena. The concepts used in the tasks are those familiar, relating to physics, chemistry, biological sciences, and earth and space sciences, but they are applied to the content of the phenomena and not just recalled. This first framework also included, as a part of the knowledge dimension, knowledge about science. The revised 2013 framework introduced conceptual, procedural and epistemic knowledge where the added procedural knowledge referred to how to do science. This involved awareness of the methods used by scientists to establish what is known and procedures that technologists and engineers used to design machines. The epistemic knowledge component was defined as 'knowledge of the constructs and defining features essential to the process of knowledge building in science and included justifying the knowledge produced by science and its role in contributing to how 'we know what we know'.

3) Scientific processes are centred on the ability to acquire, interpret and act upon evidence.

Three such processes present in PISA related to:

1) describing, explaining and predicting scientific phenomena;

2) evaluating and identifying scientific issues, such as asking questions, planning and conducting investigations and understanding scientific investigation, and

3) interpreting data and evidence scientifically and drawing evidence-based conclusions.

The initial PISA framework further introduced personal, local and global situations and contexts in three main areas: science in life and health, science in the Earth and its environment, and science in technology (OECD, 2007). 


\section{Transversal competencies}

Transversal competencies, also called key competencies, generic competencies, or 21stcentury competencies, have been an important education policy topic worldwide and refer to the knowledge and skills, or competencies the next generation are expected to learn at school (Reimers \& Chung, 2016). Many supranational organisations, such as the Organisation for Economic Co-operation and Development (OECD) and the European Union (EU), have published documents, which outline transversal competencies using specific frameworks. Following these models describing transversal competencies, countries worldwide have proposed their own frameworks involving transversal competencies. These transversal competency frameworks suggest a global trend toward reform of learning for the future, changing the focus from knowledge to competencies, in line with a later EU declaration that 'education plays a key role in ensuring that citizens acquire the key competencies needed to live in our changing world' (Council of the European Union, 2019).

One of the first descriptions of transversal competencies was put forward by the OECD's Definition and Selection of Competencies (DeSeCo) project (OECD, 2005). According to DeSeCo, individuals in the 21st century need to be able to use a wide range of tools - including socio-cultural (language) and digital (technological) - to interact effectively with the environment, to engage and interact in a heterogeneous group, to perform inquiry-oriented work and problem solving, to take responsibility for managing their own lives, and to act autonomously. In this environment, both critical and creative thinking are needed to gain these competencies. The DeSeCo document influenced the preparation of the 2014 Finnish compulsory school curriculum and its science curriculum component.

Two interesting, new descriptions of transversal competencies have been published. The Council of the European Union (2019) has published a description of key competencies (transversal competencies) for lifelong learning. These key competencies are put forward as "a combination of knowledge, skills and attitudes, where:

1) knowledge is composed of the facts and figures, concepts, ideas and theories, which are already established and support the understanding of a certain area or subject;

2) skills are defined as the ability and capacity to carry out processes and use the existing knowledge to achieve results, and

3) attitudes describe the disposition and mind-sets to act or react to ideas, persons or situations." 
Thus, key competencies are those, which all individuals need for personal fulfilment and development, employability, social inclusion, sustainable lifestyle, successful life in peaceful societies, health-conscious life management and active citizenship. The key competence document sets out eight key competencies for education: literacy competence; multilingual competence; mathematical competence and competence in science, technology and engineering; digital competence; personal, social and learning to learn competence; citizenship competence; entrepreneurship competence; and cultural awareness and expression competence (Council of the European Union, 2019).

The OECD document on the Future of Education and Skills 2030 (Vincent-Lancrin et al., 2019) introduces three areas of future skills: practical and physical skills, including problem-solving and inquiry skills; cognitive and meta-cognitive skills, such as critical and creative thinking; social and emotional skills, including a willingness to engage in different activities and collaboration skills. The practical and physical skills include two main views: 'know what and know how'. In this, the two new descriptions include partly similar views to transversal competencies by DeSeCo (OECD, 2005). Actually, most transversal competency models are emphasising the importance of critical and creative thinking, problem-solving and collaboration skill, and an understanding of core ideas or concepts. Moreover, all models stress the importance of learning digital skills. However, the DeSeCo did not emphasise attitudes or socio-emotional learning similarly to the new models. The OECD utilised the outcomes of the DeSeCo project when designing the PISA Scientific Literacy Framework, which was first used for designing the PISA test item structure (Ananiadou \& Claro, 2009).

In addition to previous descriptions of transversal competencies, there are several other descriptions under the heading of transversal, generic, lifelong learning, or key, skills or competencies (Voogt \& Roblin, 2012). For example, Care and Luo (2016) describe transversal competencies as 'skills, values and attitudes that are required for learners' holistic development and for learners to become capable of adapting to change' and are also known in the literature as employability skills (Markes, 2006), generic skills (Bennett et al., 2000), and twenty-first-century skills (Council, 2013).

Unfortunately, the implementation of transversal competencies in the school curricula and how to acquire these competencies through various learning activities is not straightforward. However, transversal competencies have been integral to the curricula in various countries (Voogt \& Roblin, 2012; Reimers \& Chung, 2016), including Finland for designing the Finnish Core Curriculum for Basic Education between 2013 and 2014 (FNBE, 2014). This implementation is in line with the general movement, where science education 
aims have been transformed from the teaching of subject knowledge to the nurturing of transversal knowledge, skills, and attitudes or competencies (Heiman \& Slomianko, 1987).

\section{Curriculum}

A national-level curriculum, in general, outlines a plan of intended goals, aims and objectives or description of learning outcomes at the national level and it guides and regulates the educational processes (Oliva, 1997). However, a national curriculum is not a neutral assemblage of goals; instead "it is produced out of the cultural, political, and economic conflicts, tensions and compromises" (Apple, 1993).

There are two major traditional curriculum theories in 'Western countries', the Anglo-American curriculum tradition and the European-Scandinavian Bildung-Didaktik tradition (Autio, 2014; Westbury, 2000). The AngloAmerican curriculum tradition usually specifies what a student should be able to do, and concrete subject matter focuses on performance and learning outcomes (Autio, 2014; Pantić \& Nataša, 2012; Westbury, 2000). Namely, the intended curriculum and teaching plans are typically well-articulated with concrete objectives in this tradition aiming to explicitly direct teachers' teaching.

By contrast, Bildung refers to an umbrella concept, or as a theory of education and covers a broader meaning than education or learning in English. In contrast to an output-oriented approach, Bildung aims to form the learner as an individual and contribute to developing his/her full potential, predicting a future of developing independence (Sjöström et al., 2017; Willbergh, 2015). The Bildung-Didaktik tradition emphasises teachers' pedagogical freedom and autonomy. Teachers are considered to be autonomous experts, with complete freedom to select their own approaches and subject matter within the 'Lehrplan', and they are not assessed in totality by the students' learning outcomes (Autio, 2014; Hopmann, 2007; Pantić \& Wubbels, 2012).

Terms that are used for describing what a teacher should teach or a student should learn can thus vary in different traditions. For example, 'goals' indicate general intentions of education. 'Aims' break down goals into measurable behaviours. 'Objectives' or 'learning outcomes' are stated in narrower, precise, concrete and measurable terms. In an Anglo-American curriculum tradition, objectives or learning outcomes focus more on what the learner should know, or be able to do, or have attained after teaching. By contrast, the BildungDidaktik tradition aims to guide teachers to plan their teaching. 


\section{Aim of this chapter}

Several studies have analysed the relationship between scientific literacy and the science curriculum aims (e.g., Bazzul, 2012; Carter, 2005; DeBoer, 2011; Sjöström et al., 2017). However, few studies have focused on analysing a curriculum from the perspective of how scientific literacy aims have been described as competencies in a curriculum, compared with, for example, the PISA Scientific Literacy framework or as descriptions of more general transversal competencies. This chapter aims to analyse how the PISA Scientific Literacy framework and other transversal competency framework aims are met in the Finnish lower-secondary science curriculum, described as a part of the Finnish Core Curriculum for Basic Education (FNBE, 2014). Within this competence development, the curriculum includes the use of scientific knowledge in various situations, although, the curriculum does not emphasise scientific knowledge as such (FNBE, 2014). However, the text related to scientific knowledge within the curriculum is shortly discussed in the contexts of visions for scientific literacy. In addition, the preparation and implementation of the science curriculum are briefly analysed.

\section{Finnish compulsory school science curriculum}

\section{General nature of the compulsory school curriculum}

In general, the Finnish curriculum can be considered to be a cocktail of the Anglo-American Curriculum and the Bildung-Didaktik (Autio, 2014; Saari et al., 2014). Historically, Finland has followed the spirit of Bildung inherited from German philosophy, justified and localised by Johan Vilhelm Snellman (Autio, 2014). After World War II, American educational psychology had been introduced into Finland and gradually integrated into the Finnish context (Saari et al., 2014). Since the 1980s, the educational system in Finland has been decentralised, meaning that most decision-making concerning the organisation and even the content of general education has been transferred to the municipalities and the schools (Niemi, Toom, \& Kallioniemi, 2016). As a part of this decentralised policy, the Finnish curriculum since 1985 has been written at two levels: the national level core curriculum and the local or municipal school level. The national core curriculum has included general aims as well as the objectives and core contents of different school subjects. Schools and municipalities have prepared the local curriculum, which considers the local context and needs, based on the national core curriculum. 
The decentralised educational system means that the Finnish teachers have autonomy and freedom to organise the classes as they want and to choose content and teaching materials, such as textbooks. The national curriculum works as a guideline for teaching instead of an entire set of requirements with detailed objectives. According to Saari et al. (2014), after the Cold War, the education policy and curriculum in Finland has emphasised the importance of economic and global competitiveness and the well-being and personal growth of students. In line with this movement towards economic and global competitiveness, transversal competencies have been emphasised to a greater extent.

Approximately every ten years, the national curriculum is revised, and Finland's latest National Core Curriculum was published in 2014. The lowersecondary science curriculum is part of the National Core Curriculum for Basic Education and is integrated into one document together with other subjects. The Finnish lower-secondary science curriculum is a combination of separate biology, physics and chemistry curricula, which are taught by a secondary teacher who specialises in two subjects, such as mathematics and physics, mathematics and chemistry, biology and geography or biology and chemistry.

Curriculum reform in 2014 aims to support scientific literacy by emphasising transversal competencies. Curriculum reform is regarded as a common tool for improving science education (Garm \& Karlsen, 2004; Young, Hall, \& Clarke, 2007). However, curriculum documents, as such, do not improve science education if science teachers do not adopt the new ideas as described in the document. Nonaka, von Krogh and Voelpel (2006) argue that implementing new ideas in practice builds on individual, group and collective learning processes where peers seek help and guidance from more expert colleagues. A similar idea is emphasised in the communities of practice or learning at the workplace or communities, where professionals access, adopt and internalise new ideas (Wenger, 1999). To achieve success in designing and putting new ideas into practice, the OECD (Burns \& Köster, 2016) recommends the following actions in designing and implementing new ideas:

1) engage stakeholders, such as teachers, teacher educators, teacher union members;

2) employ organisations to design the new ideas;

3) strive for consensus in the design;

4) allocate sustainable resources for the design and implementation of the ideas;

5) organise pilot projects;

6) disseminate the outcomes from pilot studies. 
In Finland, the 2014 curriculum reform started at the political level, where the government emphasised that transversal competencies should be integrated into the curricula and especially subject-specific curricula (Change in Basic Education Act, 642/2010). The framework curriculum was designed during the years 2013 and 2014, based on a few guiding questions related to the reform put forward by the National Board of Education (Vahtivuori-Hänninen et al., 2014):

1) What will education mean in the future? What types of competencies will be needed in everyday and working-life situations? What kind of learning environments and practices or teaching methods will best produce the desired education and learning?

2) How will change be realised at the municipal and school level, and even in every lesson?

3) What kind of competencies will teachers and other school staff need to be able to collaborate and promote learning in the future?

4) How does the national core curriculum guide the preparation of the local curriculum and support the work of teachers and the whole school community? (FNBE, 2014)

The preparation process was collaborative, as was the normal procedure. A group of experts - involving pre-primary classroom teachers and subject teachers, principals, teacher trainers, educational scientists, researchers from different subject areas, and representatives of various stakeholders, designed a draft curriculum. The whole process was transparent and publicly accessible through social media tools, a variety of different open discussion forums, and local meetings held in various parts of Finland.

After the expert team completed the draft curriculum, it was uploaded to the Finnish National Board of Education website for comment. All teachers, teacher educators, stakeholders, and even parents were able to comment freely on the draft. The comments were read, and a content analysis of these comments undertaken, then a new draft, based on the comments, was prepared and posted on the website, again for the comment. The involvement of the various stakeholders and their feedback in the design process was essential for the implementation. The stakeholders felt involved in the implementation of the curriculum in the way Ogborn (2002) described it as the development of ownership of the curriculum'.

The above questions guided the design of the curriculum, including the discussions about the transversal competencies needed in the 21 st century (Vahtivuori-Hänninen et al., 2014). The core curriculum described, in general, that transversal competencies consisted of knowledge, skills, values, attitudes 
and 'will' (FNBE, 2014). These competencies were grouped under the following competence areas in the curriculum:

1) taking care of oneself and managing daily life;

2) multi-literacy;

3) digital competence;

4) working life competence and entrepreneurship skills;

5) participation involvement and building a sustainable future;

6) thinking and learning to learn; and

7) cultural competence, interaction, and expression (FNBE, 2014).

\section{Introduction of the Finnish science curriculum in the context of PISA Scientific Literacy framework}

While designing the aims for science teaching in Finland, the PISA Scientific Literacy framework and competencies, described in the framework, are present in the discussion. The PISA competencies are grouped under the following areas: attitudes, scientific knowledge or concepts, scientific processes and situations or contexts. In Table 1 below, PISA Scientific literacy competencies and competencies in the science curriculum in the National Core Curriculum are compared.

Table 1. Comparison of PISA Scientific literacy competencies and competencies in the science curriculum in the National Core Curriculum

\begin{tabular}{|c|c|}
\hline $\begin{array}{l}\text { PISA Scientific literacy } \\
\text { competencies }\end{array}$ & $\begin{array}{l}\text { Example of Competencies in the science curriculum in the National } \\
\text { Core Curriculum }\end{array}$ \\
\hline \multicolumn{2}{|l|}{ Attitudes } \\
\hline $\begin{array}{l}\text { - Support for scientific } \\
\text { enquiry }\end{array}$ & $\begin{array}{l}\text { - experimental learning creates the joy of learning and influences pupils' } \\
\text { interest ... (biology) }\end{array}$ \\
\hline $\begin{array}{l}\text { - Self-belief as science } \\
\text { learners }\end{array}$ & $\begin{array}{l}\text { _... support and selection of teaching methods participation in the } \\
\text { planning of activities and success support the pupils in reinforcing their } \\
\text { self-image as learners. (physics) } \\
\text { _... guide pupils to perceive the significance of their competence in } \\
\text { chemistry, ... also for further studies ... }\end{array}$ \\
\hline - Interest in science & $\begin{array}{l}\text { - } \ldots \text { to encourage and inspire the pupils to study chemistry } \\
\text { - } \ldots \text { interest in nature and its phenomena ... relation to nature .... } \\
\text { (biology, physics, chemistry) }\end{array}$ \\
\hline $\begin{array}{l}\text { - Responsibility towards } \\
\text { resources and } \\
\text { environments }\end{array}$ & $\begin{array}{l}\text { - the pupils are guided towards a sustainable way of living and } \\
\text { understanding global responsibility (biology) } \\
\text { _ significance of physics in building a sustainable future } \\
\text { - } \ldots \text { students are guided to take responsibility for their environment ... } \\
\text { make choices ... (chemistry) }\end{array}$ \\
\hline
\end{tabular}




$\begin{array}{ll}\begin{array}{l}\text { PISA Scientific literacy } \\ \text { competencies }\end{array} & \begin{array}{l}\text { Example of Competencies in the science curriculum in the National } \\ \text { Core Curriculum }\end{array} \\ \begin{array}{ll}\text { Scientific knowledge or concepts } \\ \text { - Use of knowledge in }\end{array} & - \text { use of biological knowledge for understanding life and its development, } \\ \text { situations } & \ldots \text { ecosystem } \\ & - \text { use knowledge for developing conceptual structures (physics) } \\ & - \text { use of knowledge in different life situations (chemistry) } \\ \text { - Nature of scientific } & - \text { characteristics of biological information acquisition ... through inquiry .... } \\ \text { knowledge and inquiry } & - \text { consistency of concepts and scientific theories (physics) } \\ & - \text { develop abstract thinking at sub-microscopic and symbolic levels }\end{array}$

\section{Scientific processes}

- Describing, explaining and predicting scientific phenomena

- Identifying scientific issues, such as asking questions and planning investigations

- Interpreting data and evidence scientifically and drawing evidencebased conclusions
- apply biological knowledge in his/her life and discussion

- ... use different models in describing and explaining phenomena and in making predictions (physics)

- use different kind of models to describe and explain the structure of matter and chemical phenomena (chemistry)

- grow plants to understand biological phenomena

- formulate questions about phenomena in focus ... further develop questions to serve as a basis for inquiry (physics \& chemistry)

- develop scientific thinking and recognise causal relationship (biology)

- ... process, interpret and present results (physics \& chemistry)

\section{Situations or contexts}

- Science in life and health
- use of biological knowledge in your own life, ... function of the body

- ... need to develop technological solutions and to secure the well-being of humans and the environment (physics)

- chemistry is needed in securing the well-being of humans

- Science in the Earth and environment

- Science in technology
- use of biological knowledge in ethical reflection ... sustainable way of living

- chemistry has an important role in building a sustainable future

- use of biological knowledge decision making and development of surrounding ... build a sustainable future

- significance of physics and technology in daily life ...

- chemistry is needed in developing technological solutions

\section{Comparison of the Finnish science curriculum to transversal competencies introduced in the DeSeCo documents}

The seven transversal competence areas, introduced above, are close to the DeSeCo definition of 21st-century competencies and are assumed to promote students' growth as human beings and as citizens for the 21 st century, as well as 
aligning with recent OECD definitions (Vincent-Lancrin et al., 2019) and the European Union's definitions of key competencies (Council of the European Union, 2019). In addition to a general description of transversal competencies, they are included under subject-specific curriculum aims. This approach is expected to help teachers understand the meaning of the competencies and how to implement them (Halinen, 2018). Moreover, it is assumed that it is easier for textbook authors and the designers of digital learning environments to design the teaching and learning materials and environments that allow for transversal competencies. In Table 2 below, the transversal competencies introduced in the DeSeCo documents (OECD, 2005) and the Finnish transversal competencies (FNBE, 2014) are compared. The comparison to DeSeCo documents is appropriate because they already exist and have influenced the planning of the transversal competencies in the curriculum.

Table 2. Comparison of transversal competencies introduced in the DeSeCo documents and Finnish transversal competencies introduced in the National Core Curriculum

\begin{tabular}{ll}
$\begin{array}{l}\text { Transversal competencies } \\
\text { introduced in DeSeCo }\end{array}$ & $\begin{array}{l}\text { Finnish transversal competencies introduced in the National Core } \\
\text { Curriculum }\end{array}$ \\
Ways of thinking & \\
\hline Critical thinking & - Pupils are instructed to find how knowledge can be built, for example, \\
& by asking questions and looking for evidence to answer these questions \\
- & $\ldots$ pupils are given an opportunity to critically analyse the issue from \\
& different perspectives \\
- & Finding innovative solutions requiring students to learn to see \\
& alternatives and unite perspectives \\
- & Exploratory and creative work, working together, and contributing to the \\
& development of thinking and learning to learn \\
- & Use information independently and interact with others for problem \\
& solving, reasoning, and making conclusions \\
- & Practicing appropriate behavioural and collaborative skills in working \\
& situations, and noticing the importance of language skills and \\
interaction skills
\end{tabular}

Ways of working

- Inquiring

- Problem solving

- Communication and collaboration

\footnotetext{
- Collaborative, inquiry-oriented and creative working

- Use information independently and interact with others for problem solving, reasoning, and making conclusions

- Practicing appropriate behavioural and collaborative skills in working life situations and noticing the importance of language skills and interaction skills
} 


\begin{tabular}{|c|c|}
\hline $\begin{array}{l}\text { Transversal competencies } \\
\text { introduced in DeSeCo }\end{array}$ & $\begin{array}{l}\text { Finnish transversal competencies introduced in the National Core } \\
\text { Curriculum }\end{array}$ \\
\hline \multicolumn{2}{|l|}{ Tools for working } \\
\hline - Information literacy & $\begin{array}{l}\text { - Cultural literacy, interaction, and communication } \\
\text { - Multi-literacy refers to the skills of interpreting, producing, and valuing } \\
\text { different texts that help students to understand diverse forms of cultural } \\
\text { communication and to build their own identity }\end{array}$ \\
\hline $\begin{array}{l}\text { - Technological skills, } \\
\text { media literacy }\end{array}$ & $\begin{array}{l}\text { - Develops skills in both traditional and multi-media environments that } \\
\text { utilise technology in different ways. } \\
\text { _ ICT skills are developed in four major areas ... and understand the use } \\
\text { and operation of ICT ... }\end{array}$ \\
\hline \multicolumn{2}{|l|}{ Acting in the world } \\
\hline $\begin{array}{l}\text { - Global and local } \\
\text { citizenship }\end{array}$ & $\begin{array}{l}\text { - Taking care of yourself, everyday life skills, and safety } \\
\text { - } \ldots \text { students grow as active citizens who act according to democratic } \\
\text { rights and responsibilities ... }\end{array}$ \\
\hline $\begin{array}{l}\text { - Cultural awareness and } \\
\text { social responsibility }\end{array}$ & $\begin{array}{l}\text { - Working life skills and entrepreneurship ... } \\
\text { - Participation and influence, taking responsibility for a sustainable future }\end{array}$ \\
\hline
\end{tabular}

\section{The subject matter knowledge, introduced in the Finnish science curriculum}

The Finnish national, lower-secondary level science curriculum emphasises the use of scientific knowledge in various situations, as described in Table 2. For example, one competence aim in physics promotes the use of different models in describing and explaining phenomena and making predictions. It has been a tradition since 1994 that competence aims are the core of the curriculum and the curriculum only outlines some examples of appropriate subject matter knowledge (Lavonen, 2007). The curriculum introduces six core domains of subject matter knowledge in physics, chemistry and biology, as introduced in Table 3 (FNBE, 2014).

Table 3. Core subject matter knowledge introduced in the science curriculum

\begin{tabular}{lcl} 
Physics & Chemistry & Biology \\
- Scientific inquiry & - Scientific inquiry & - Scientific inquiry \\
- Physics in your own life & - Chemistry in your own life and & - Investigations to nature and \\
and living environment & living environment & environment \\
(design of solutions) & (design of solutions) & - Structure of Ecosystem \\
- Physics in the society & - Chemistry in the society & - What is life? \\
- Physics shaping the & - Chemistry shaping the worldview & - Human being \\
worldview & - Properties and structure of & - Towards a sustainable future \\
- Interaction and motion & substances & \\
- Electricity & - Symbolic level in Chemistry and & \\
& structure of matter & \\
\hline
\end{tabular}


In addition to the titles of core subject matter knowledge, a short description of each domain of subject matter knowledge is introduced in the curriculum. Three examples are presented below.

Electricity: The electric circuit is suggested to be analysed through the connection between voltage and electric current. The phenomena in the electric circuit are first studied qualitatively and then through measuring voltage and electric current while examining the dependencies between these quantities. The subject matter knowledge is also selected in connection with electrical safety at home. Electrical charging and magnetism are qualitatively analysed.

Properties and structure of substances: The properties of mixtures and pure substances such as water and fat solubility are studied in various ways. Based on the properties of elements, the structure of matter from atoms, the structure of the atom and the periodic table are studied. Models and simulations are used for visualising the structure of compounds. Carbon, its compounds and organic groups of compounds are introduced.

Human being: The focus is on studying the functioning of the human body and the knowledge of the human structure, vital functions and regulatory systems. The rationale for the biological factors that affect growth, development, and health and how genetics and the environment affect the development of different human characteristics are analysed.

\section{Implementation of the science curriculum at the local level}

The preparation of a local curriculum in Finland has engaged science teachers to become familiar with the transversal competencies at two levels. First, teachers become familiar with the new curriculum and the overview of transversal competencies by participating in the discussion and commenting on the preparation of the national level curriculum. The National Board of Education has organised meetings all over the country during the preparation process. Second, during the local curriculum process, science teachers have been active in the preparation of the local curriculum and have described in detail how the learning and assessment of transversal competencies are integrated into science teaching and learning. According to Jauhiainen (1995) and Holappa (2007), local curriculum processes have always inspired and empowered teachers and principals to design the local curriculum and lessons according to the curriculum.

In order to support the learning of transversal competencies in science classrooms, the 2014 curriculum framework emphasises collaborative classroom practices and engagement of students in multidisciplinary, phenomena and project-based studies. According to the curriculum, in addition to 
the integration of transversal competencies into the teaching of science, all schools, design and provide at least one annual study period, which focuses on phenomena that are of special interest to students. It is expected that students are encouraged to participate in the planning process of these studies.

To support schools in preparing and implementing the curriculum, the National Board of Education has established the Majakka-network (FNBE, 2016). This network organises meetings and supports teachers in planning the implementation of transversal competencies in their teaching. Additionally, in 2017, the National Board of Education has allocated 100 million euros to appoint tutor teachers who can support the teachers in their classrooms to implement the transversal competencies within their teaching (MEC 2017). Altogether, 2,000 tutor teacher positions have been created in Finnish municipalities to support the teaching and learning of transversal competencies (Oppiminen uudistuu, 2018).

\section{Discussion}

The Finnish Curriculum is an integration of a Bildung-Didaktik and AngloAmerican curriculum tradition. However, there is no concrete and well-structured content list in the Curriculum, but rather a broad thematic content and an emphasis on the use of knowledge. It implies a connection to the Didaktik tradition, whose aims, as shown in the Curriculum, are formulated from the instructional perspective of the teacher.

This chapter has analysed how the aim for scientific literacy and the acquisition of transversal competencies are met in the lower-secondary science curriculum, which is described as a part of the Finnish Core Curriculum for Basic Education (FNBE, 2014). The scientific literacy aims have been put forward in this chapter by describing literacy as competence aims, which have been approached through the PISA Scientific Literacy and general transversal competency frameworks, as described in Tables 1 and 2.

The introduction of the Finnish science curriculum in the context of the PISA Scientific Literacy framework (OECD, 2007) in Table 1 demonstrates that the physics, chemistry and biology curricula covers the PISA framework's domains. The science curriculum emphasises attitudes, which support the use of scientific knowledge in different science inquiry situations and contexts. The competence aims emphasise the use of scientific knowledge in describing, explaining and predicting scientific phenomena, evaluating and identifying scientific issues, such as asking questions, planning and conducting investigations and understanding scientific investigation, and interpreting data and 
evidence scientifically and drawing evidence-based conclusions, as they are set out in the PISA Scientific Literacy framework. This type of orientation, which stresses the use of knowledge in various situations, is easily recognised in various modern curricula, such as in the US Next Generation Science Standards (NGSS, Next Generation Science Standards, NGSS Lead States, 2013). The Finnish science curriculum introduces the "use of scientific knowledge" in various situations, such as in life and health, in the Earth and the environment, and in technology.

In addition to the PISA Scientific Literacy framework competence aims, general transversal competencies have been integrated into the science aims. The content analysis of the transversal competencies, introduced in the Finnish lower secondary curriculum, are in line with the OECD DeSeCo transversal competencies. The lower secondary curriculum emphasises, especially learning of critical and creative thinking skills and moreover 'learning to learn' competencies. The description of Finnish transversal competencies emphasises the learning of versatile ways of working, such as inquiring, problem-solving, communication and collaboration. It emphasises learning about the use of concrete tools, such as digital tools and information literacy. Finally, the description of Finnish transversal competencies emphasises working in various situations and contexts.

The transversal competencies are described in 7 categories: taking care of oneself, managing daily life; multi-literacy; digital competence; working life competence, entrepreneurship; participation involvement, building a sustainable future; thinking and learning to learn; and cultural competence, interaction, and expression and are almost identical to those put forward by the Council of the European Union (2019). Moreover, the description is also close to the OECD Future of Education and Skills 2030 (Vincent-Lancrin et al., 2019). The implementation of transversal competencies can be emphasised, for example, in collaborative classroom practices through engaging students in multidisciplinary, phenomena- and project-based studies. However, there is autonomy for teachers and municipality-level authorities for designing the curriculum and developing their own innovative approaches for implementing the transversal competencies into teaching and learning.

As it is recognised in Table 3, the science subject matter knowledge introduced in the science curriculum is not a traditional description of subject matter. The curricula in physics, chemistry and biology also emphasise the use of knowledge in inquiry, life and living and society related situations. The subject matter knowledge also supports the shaping of a worldview. In physics and chemistry, there are two core subject matter areas that are covered, and in biology it is three. The limitation of the subject matter knowledge to only a few 
areas aims to offer more time in the classrooms to engage in the learning of science and transversal competencies. The description of core subject matter knowledge aims to integrate - Vision I (conceptual approach) and Vision II (contextual approach) related to science literacy (Roberts, 2007). The emphasis in the connection of competencies to contexts, such as 'sustainable development' and 'wellbeing', means that utility and meaningfulness of science, or Vision II, is emphasised in the curriculum, more than Vision 1. Vision III (critical approach) does not explicitly appear in the curriculum, but to some extent intentions for Vision III arise in the curriculum, for example, describing environmental awareness and emphasising connections with society (Hodson, 2011). However, these references are rather implicit.

The design and implementation of the national framework curricula are supported by goal orientation, planning, designing and timing, collaboration and networking, and a reflective orientation (Burns \& Köster, 2016). Collaboration and networking created forums have been set up for discussing the challenges in science education, as well as for setting strategic aims to support designing the core curriculum (Kitchen \& Figg, 2011; Paavola \& Hakkarainen, 2014). These supportive characteristics for implementing the core curriculum help teachers prepare the local curriculum and their professional learning (Maier \& Schmidt, 2015).

In 2018, the Finnish Education Evaluation Centre evaluated the implementation of the national core curriculum at the local level and the process of preparing the local curriculum, by analysing the local curriculum by all education providers. Moreover, the Centre has interviewed curriculum specialists to learn about the success and challenges of implementing the local level curriculum. According to the evaluation, the national and local steering systems support the implementation of the curriculum, as well as classroom teaching. Moreover, the transversal competencies are being integrated with the aims of the school subjects at the school level, and teachers are aware of this integration. However, there are challenges with integrating the transversal competencies into classroom teaching and learning (Saarinen, et al. 2019). Nevertheless, it is seen as too early to evaluate the level of impact of the curriculum and development programmes have had on education practices or how well the curriculum and programme support teacher education and schools to overcome the identified challenges in education. 


\section{References}

Ananiadou, K., \& Claro, M. (2009). 21st century skills and competencies for new millennium learners in OECD countries: OECD Education Working Papers, 41. Paris: OECD Publishing. https://doi.org/10.1787/218525261154

Apple, M. W. (1993). The politics of official knowledge: Does a national curriculum make sense? Discourse: Studies in the Cultural Politics of Education, 14(1), 1-16. https://doi.org/10.1080/0159630930140101

Autio, T. (2014). The Internationalization of Curriculum Research. In W. Pinar (Ed.), International handbook of curriculum research (pp. 17-31). New York, NY: Routledge.

Bazzul, J. (2012). Neoliberal ideology, global capitalism, and science education: Engaging the question of subjectivity. Cultural Studies of Science Education, 7(4), 1001-1020. https://doi.org/10.1007/s11422-012-9413-3

Bennett, N., Dunne, E., \& Carré, C. (2000). Skills Development in Higher Education and Employment. The Society for Research into Higher Education and Open University Press.

Burns, T., \& Köster F. (Eds.) (2016). Governing Education in a Complex World. Paris: OECD Publishing. https://doi.org/10.1787/9789264255364-en

Bybee, R., \& McCrae, B. (2011). Scientific Literacy and Student Attitudes: Perspectives from PISA 2006 science. International Journal of Science Education, 33(1), 7-26. https://doi.org/10.1080/09500693.2010.518644

Care, E., \& Luo, R. (2016). Assessment of Transversal Competencies: Policy and Practice in the Asia-Pacific Region. United Nations Educational, Scientific and Cultural Organization (UNESCO).

Carter, L. (2005). Globalisation and science education: Rethinking science education reforms. Journal of Research in Science Teaching, 42(5), 561-580. https://doi.org/10.1002/tea.20066

Change in Basic Education Act (Laki perusopetuslain muuttamisesta) 642/2010. Retrieved from http://www.finlex.fi/fi/laki/alkup/2010/20100642.

Council of the European Union (2019). Key competences for lifelong learning. Council of the European Union. https://op.europa.eu/en/publication-detail/-/publication/ 297a33c8-a1f3-11e9-9d01-01aa75ed71a1.

Council, N. R. (2013). Education for life and work: Developing transferable knowledge and skills in the 21st century. National Academies Press.

DeBoer, G. E. (2011). The globalization of science education. Journal of Research in Science Teaching, 48(6), 567-591. https://doi.org/10.1002/tea.20421

Finnish National Board of Education (2016). National core curriculum for basic education 2014. Helsinki: National Board of Education.

FNBE [Finnish National Board of Education] (2014). The National Core Curriculum for Basic Education. Helsinki: FNBE National Board of Education. Retrieved from https://eperusteet.opintopolku.fi/beta/\#/fi/. 
Garm, N., \& Karlsen, G.E. (2004). Teacher education reform in Europe: The case of Norway; Trends and tensions in a global perspective. Teaching and Teacher Education, 20(7), 731-744. https://doi.org/10.1016/j.tate.2004.07.004

Halinen, I. (2018). The new educational curriculum in Finland. In M. Matthes, L. Pulkkinen, C. Clouder, \& B. Heys (Eds.), Improving the quality of childhood in Europe: Volume 7 (pp. 75-89). Brussels: Alliance for Childhood European Network Foundation. Retrieved from http://www.allianceforchildhood.eu/files/Improving the_quality_of_Childhood_Vol_7/QOC\%20V7\%20CH06\%20DEF \%20WEB.pdf.

Heiman, M., \& Slomianko, J. (Eds.). (1987). Thinking skills instruction: Concepts and techniques. Washington, DC: National Education Association. Retrieved from http://files.eric.ed.gov/fulltext/ED306559.pdf.

Hodson, D. (2011). Looking to the future: Building a curriculum for social activism. Rotterdam: Sense. https://doi.org/10.1007/978-94-6091-472-0_3

Holappa, A.-S. (2007) Perusopetuksen opetussuunnitelma 2000-luvulla - uudistus paikallisina prosesseina kahdessa kaupungissa [Curriculum of Basic School in 2000 Century: Renewal of Local Curriculum in two Cities]. Acta Universitatis Ouluensis. series E 94. Oulun yliopisto. Kasvatustieteiden tiedekunta.

Holbrook, J. (2010). Education through Science as a Motivational Innovation for Science Education for All. Science Education International, 21(2), 80-91.

Hopmann, S. (2007). Restrained teaching: The common core of Didaktik. European Educational Research Journal, 6(2), 109-124. https://doi.org/10.2304/eerj.2007.6.2.109

Jauhiainen, P. (1995). Opetussuunnitelmatyö koulussa. Muuttuuko yläasteen opettajan työ ja ammatinkuva? [Preparation of a local curriculum: How do teacher professionalism and identity change?]. Tutkimuksia 154. Helsingin yliopiston opettajankoulutuslaitos.

Kitchen, J., \& Figg, C. (2011) Establishing and sustaining teacher educator professional development in a self-study community of practice: Pre-tenure teacher educators developing professionally. Teaching and Teacher Education, 27(5), 880-890. https://doi.org/10.1016/j.tate.2011.02.003

Lavonen, J. (2007). National science education standards and assessment in Finland. In D. Waddington, P. Nentwig \& S. Schaze (Eds.), Making it comparable (pp. 101126). Berlin: Waxmann.

Levinson, R. (2010). Science education and democratic participation: An uneasy congruence? Studies in Science Education, 46(1), 69-119. https://doi.org/10.1080/03057260903562433

Maier, R., \& Schmidt, A. (2015). Explaining organizational knowledge creation with a knowledge maturing model. Knowledge Management Research \& Practice, 13(4), 361-381. https://doi.org/10.1057/kmrp.2013.56

Markes, I. (2006). A review of literature on employability skill needs in engineering. European Journal of Engineering Education, 31(6), 637-650.

https://doi.org/10.1080/03043790600911704 
Ministry of Education and Culture (MEC). (2017). Osaamiseen ja tutkimukseen isot lisäpanostukset ensi vuoden budjetissa [Next year's budget promises more resources for education]. Ministry of Education and Culture. Retrieved from http://minedu. fi/artikkeli/-/asset_publisher/osaamiseen-koulutukseen-ja-tutkimukseen-isotlisapanostukset-ensi-vuoden-budjetissa.

NGSS Lead States. (2013). Next Generation Science Standards: For states, by states. Washington, DC: The National Academies Press.

Niemi, H. Toom, A., \& Kallioniemi, A. (2012). Miracle of education: The principles and practices of teaching and learning in Finnish schools. Rotterdam: Sense Publishers. https://doi.org/10.1007/978-94-6091-811-7

Nonaka, I., von Krogh, G., \& Voelpel, S. (2006). Organizational knowledge creation theory: Evolutionary paths and future advances. Organization Studies, 27(8), 1179-1208. https://doi.org/10.1177/0170840606066312

OECD (2005). Definition and selection of competencies (DeSeCo): Executive summary. Paris: OECD Publishing. Retrieved from http://www.oecd.org/pisa/35070367.pdf.

OECD (2007). PISA 2006: Science competencies for tomorrow's world, volume 1: Analysis. Paris: OECD. https://doi.org/10.1787/9789264040014-en

OECD (2013). PISA 2012. Results in focus. What 15-year-olds know and what they can do with what they know. Paris: OECD Publishing. Retrieved from http://www. oecd.org/pisa/keyfindings/pisa-2012-results-overview.pdf.

Ogborn, J. (2002). Ownership and transformation: Teachers using curriculum innovations. Physics Education, 37, 142-146.

https://doi.org/10.1088/0031-9120/37/2/307

Oliva, P. (1997). The Curriculum: Theoretical Dimensions. New York: Longman.

Oppiminen uudistuu (2018). Tasa-arvoisen peruskoulun tulevaisuus: Koulutustakuusta osaamistakuuseen [The future of equal primary school: From training skills to knowledge skills]. Retrieved from https://oppiminenuudistuu.wordpress.com/category/uusi-peruskoulu/.

Reimers, F. M., \& Chung, C. K. (2016). A comparative study of the purposes of education in the twenty-first century. In F. M. Reimers \& C. K. Chung (Eds.), Teaching and learning for the twenty-first century: Educational goals, policies, and curricula from six nations (pp. 1-24). Cambridge: Harvard Education Press.

Roberts, D. A. (2007). Scientific literacy/ science literacy. In S. K. Abell \& N. G. Lederman (Eds.), Handbook of research on science education (pp. 729-780). Mahwah, N. J: Lawrence Erlbaum Associates (LEA).

Roberts, D. B., \& Bybee, W. R. (2014). Scientific literacy, science literacy, and science education. In N. G. t. Lederman \& S. K. t. Abell (Eds.), Handbook of research on science education. (Vol. 2, pp. 545-558). New York: Routledge.

Saari, A., Salmela, S., \& Vilkkilä, J. (2014). Governing Autonomy. In W. Pinar (Ed.), International handbook of curriculum research (pp. 183-200). New York, NY: Routledge. 
Sjöström, J., Frerichs, N., Zuin, V., \& Eilks, I. (2017). Use of the concept of Bildung in the international science education literature, its potential, and implications for teaching and learning. Studies in Science Education, 53(2), 165-192. https://doi.org/10.1080/03057267.2017.1384649

Vahtivuori-Hänninen, S. H., Halinen, I., Niemi, H., Lavonen, J. M. J., Lipponen, L., \& Multisilta, J. (2014). A new Finnish national core curriculum for basic education and technology as an integrated tool for learning. In Niemi, H., Multisilta, J., Lipponen, L., \& M. Vivitsou (Eds.), Finnish innovations \& technologies in schools: A guide towards new ecosystems of learning (pp. 33-44). Sense Publishers. https://doi.org/10.1007/978-94-6209-749-0_2

Vincent-Lancrin, S., González-Sancho, C., Bouckaert, M., de Luca, F., FernándezBarrerra, M., Jacotin, G., Urgel, J., \& Vidal, Q. (2019). Fostering students' creativity and critical thinking: What it means in school, educational research and innovation. OECD Publishing. https://doi.org/10.1787/62212c37-en

Voogt, J., \& Roblin, N. P. (2012). A comparative analysis of international frameworks for 21st century competencies: Implications for national curriculum policies. Journal of Curriculum Studies, 44(3), 299-321. https://doi.org/10.1080/00220272.2012.668938

Wenger, E. (1999). Communities of practice: Learning, meaning, and identity. Cambridge University Press.

Westbury, I. (2000). Teaching as a reflective practice: what might Didaktik teach Curriculum? In S. Hopmann, K. Riquarts, \& I. Westbury (Eds.), Teaching as a reflective practice: The German Didaktik tradition. Mahwah, NJ: Lawrence Erlbaum Associates.

Willbergh, I. (2015). The problems of 'competence' and alternatives from the Scandinavian perspective of Bildung. Journal of Curriculum Studies, 47(3), 334-354. https://doi.org/10.1080/00220272.2014.1002112

Young, J. C., Hall. C., \& Clarke, A. (2007). Challenges to university autonomy in initial teacher education programmes: The cases of England, Manitoba, and British Columbia. Teaching and Teacher Education, 23, 81-93.

https://doi.org/10.1016/j.tate.2006.04.008 